The Egyptian Journal of Hospital Medicine (January 2019) Vol. 74 (2), Page 262-269

\title{
The Role of Visceral Fat, IL-6, Adiponectin and Leptin Levels on Reflux Esophagitis in Obese Patients
}

\author{
Salem Soliman Ahmed Salama, Abd El-Monem Mohamed Barrak, Amin Mahmoud Hejazi Kamel \\ Soliman Hammad, Ahmed Farag Abd-Alkader*
}

Internal Medicine Department, Faculty of Medicine, Al-Azhar University, Cairo, Egypt

*Corresponding author: Ahmed Farag Abd-Alkader, E-mail: dr.ahmed.farag2018@gmail.com

\begin{abstract}
Background: Gastroesophageal reflux disease (GERD) is one of the most common problems encountered in clinical practice today. The pathophysiology of GERD is complex, involving diverse factors.

Aim of the work: was to assess the role of visceral fat and IL-6, adiponectin and leptin levels on reflux esophagitis in obese patients.

Patients and Methods: This prospective observational case-control study included a total of 90 participants; 60 patients with reflux esophagitis and 30 age and sex-matched healthy controls. Evaluation of the Role of Visceral Fat, IL-6, Adiponectin and Leptin Levels on Reflux Esophagitis in Obese Patients was done.

Results: An overall 90 patients were enrolled in this study, 50 males and 40 females, were assorted into three groups, obese and had GERD group, non-obese and had GERD, included 30 patients (33.3\%),17 males (56.7\%) and 13 females (43.3\%), and control group, included 30 patients (33.3\%), 18 males (60\%) and 12 females (40\%). The mean levels of body mass index, weight circumference, fasting-plasma glaucous, two hours post-prandial plasma glucose, Creatinine, liver enzymes, and lipid parameters were elevated in obese group when compared with non-obese and control groups. Consequently, the mean levels of leptin and interleukin-6 were high in obese group in comparison with other groups. Interestingly, the mean level of adiponectin was high in non-obese group in comparison with obese and control groups.

Conclusion: Inflammatory cytokines, adipokines, and visceral fat referring abdominal obesity had an association with reflux esophagitis.

Keywords: reflux esophagitis, obesity, adiponectin, leptin, visceral fat

\section{Introduction}

Gastroesophageal reflux disease (GERD) is one of the most common problems encountered in clinical practice today ${ }^{(\mathbf{1})}$. The pathophysiology of GERD is complex, involving diverse factors such as gastric acid secretion, dysfunction of the antireflux barrier, gastric emptying disturbances, and abnormalities in esophageal defense mechanisms. These different factors of GERD are incompletely understood, however they all share one common initiating event: increased exposure of the esophageal epithelium to gastric contents, mainly acid, pepsin, trypsin, and bile acids $^{(2)}$. Mucosal injury, characterized by a nonspecific inflammatory reaction surrounding the acid damaged epithelial cells, may occur in the setting of pathological reflux. This leads to the endoscopic findings of mucosal breaks, strictures, columnar metaplasia (Barrett's esophagus), and adenocarcinoma ${ }^{(3)}$.

Obesity is strongly associated with inflammation, presumably because of an increase in visceral fat and other tissues such as the liver secreting proinflammatory cytokines (e.g., interleukin [IL$6)^{(4)}$. Subsequently, abdominal visceral adipose tissue seem to have a major rule in the pathophysiology of GERD not only the metabolic effects but also its mechanical effect as a part of increasing the intraabdominal pressure that leads to disturbances of the sphincter, and esophageal motility functions ${ }^{(\mathbf{5})}$. Furthermore, it was established that abdominal visceral adipose tissue may be an optimal predictor of GERD among obese patients even better than body mass index, and weight circumference ${ }^{(6)}$. Visceral fat is an important endocrine organ that secretes different bioactive substances such as adipocytokines. Thus, obesity may affect the pathogenesis of
\end{abstract}


GERD by acid reflux as well as adipocytokines (7). These adipokines, such as adiponectin and leptin, which may regulate inflammation and cell proliferation. In contrast, obesity is associated with changes in the circulating levels of these adipokines. Leptin is secreted in proportional to fat mass, and it has been proposed as a pathophysiologic mediator of GERD $^{(8)}$. Moreover, leptin's intracellular signaling pathway is similar to that of inflammatory cytokines in several models including in vitro models of Barrett's esophagus (BE). Also, adiponectin is a protein secreted by adipocytes in the visceral adipose tissue in inverse proportion to fat mass, 12 and it has an anti-inflammatory effect $^{(\boldsymbol{9})}$.

The literature is still obscure and limited regarding the actual relationship between visceral fat, adipokines and GERD. Hence, we conducted this study to assess the role of visceral fat, IL-6, adiponectin, and leptin levels on reflux esophagitis in obese patients.

\section{Patients and Methods:}

This prospective observational case-control study included a total of 90 participants; 60 patients with reflux esophagitis and 30 age and sexmatched healthy controls attending at the Internal Medicine Department, Bab-El-Shaaryia University Hospital, Faculty of Medicine, AlAzhar University. Approval of the ethical committee and a written informed consent from all the subjects were obtained. This study was conducted between May 2016 to October 2018.

Evaluation of the Role of Visceral Fat, IL-6, Adiponectin and Leptin Levels on Reflux Esophagitis in Obese Patients was done.

\section{Inclusion criteria}

Patients with clinical evidence of GERD in terms of heart burn, non-cardiac chest pain, regurgitation, dyspepsia, dysphagia, odynophagia, chronic pharyngitis, laryngitis, and chronic cough, based on esophago-gastroduodenoscopy findings.

\section{Exclusion criteria}

Patients with previous gastric surgery, patients who did not perform the Helicobacter pylori test, patients on treatment by proton pump inhibitors, diabetic patients, heavy smokers, alcoholics, pregnancy, and patients suffered from diaphragmatic hernia (hiatus hernia).

\section{Data collection}

All 60 patients with reflux esophagitis (30 obese and 30 non-obese (lean body) enrolled in the stu dy were subordinated to meticulous history takin g, physical examination and esophagogastroduod enoscopy.

History taking comprehending age, sex, comorbidities (hypertension, chronic liver diseases, chronic renal insufficiency, cardiac insufficiency, and other chronic diseases) Furthermore, rigorous physical examination was performed to retrieve the parameters of obesity particularly weight, body mass index(BMI), and weight circumference(WC). Subsequently, to evaluate the presence of non-alcoholic fatty live disease (NAFLD), all patients were subjected to abdominal ultrasonography(US) and were evaluated based on the scoring system of Hamaguchi et $a \mathbf{l}^{(\mathbf{1 0})}$. Moreover, visceral adiposity index(VAI) was evaluated based on Amato et al. (11), whilst adequate samples were collected for the optimal assessment of adiponectin, leptin, and interleukin-6 (IL-6). Eventually, all patients were submitted to routine investigations comprehending blood profile, lipid profile, renal function test, and liver function tests.

\section{Esophagogastroduodenoscopy}

Esophagogastroduodenoscopy was performed using a flexible endoscope (Q260; Olympus Optical, Tokyo, Japan) after overnight fasting. Reflux esophagitis defined as proven reflux esophagitis excluding minor change. The severity of reflux esophagitis was graded from A to D according to the Los Angeles classification system. During each endoscopic examination, rapid urease test (Pronto Dry; Medical Instruments, Solothurn, Switzerland) using a biopsy specimen obtained at the greater curvature of the body of the stomach was done to evaluate H. pylori. Barrett's esophagus was defined as an esophagus in which any portion of the normal distal squamous epithelial lining was replaced by columnar epithelium that was clearly visible endoscopically $(1 \mathrm{~cm})$ above the gastroesophageal junction according to the British Society of Gastroenterology guidelines on the diagnosis and management of BE. 


\section{Statistical analysis}

Statistical analysis was performed using SPSS software version 17 for Windows (SPSS Inc., Chicago, IL, USA). McNamara's exact test was used to compare categorical paired variables. For continuous outcomes, we used Wilcoxon sign rank test for non-normally distributed data, and student t-test for normally distributed data. Correlation analysis was performed using the Pearson correlation coefficient for continuous normally-distributed variables, while the Spearmann rank correlation was used for other variables. All tests were considered significant when $\mathrm{P}<0.05$.

\section{Results}

Demographics and clinical characteristics:

An overall 90 subjects were enrolled in the study, 50 males and 40 females, were assorted into three groups, obese and had GERD group, included 30 subjects (33.3\%), 15 males (50\%) and 15 females $(50 \%)$, with mean age was $42.27 \pm 9.35$ years. The mean BMI was $30.27 \pm 2.53 \mathrm{Kg} / \mathrm{m}^{2}$ whilst the mean waist circumference was $93.23 \pm 5.01$ $\mathrm{cm}$. The second group was non- obese and had GERD, included 30 patients (33.3\%), 17 males $(56.7 \%)$ and 13 females (43.3\%), with mean age of $41.77 \pm 6.58$ years. Moreover, the mean BMI were $23.57 \pm 2.14 \mathrm{Kg} / \mathrm{m}^{2}$ whilst, the mean waist circumference was $80.53 \pm 4.02 \mathrm{~cm}$. Consequently, the third control group, included 30 patients $(33.3 \%), 18$ males $(60 \%)$ and 12 females $(40 \%)$, and the mean age was $38.33 \pm$ 11.1 years while the mean BMI was $21.03 \pm 1.59$ $\mathrm{Kg} / \mathrm{m}^{2}$, and the mean waist circumference was $77.67 \pm 3.44 \mathrm{~cm}$.

Among the obese group there were $6(20 \%)$ patients with grade A reflux, while $10(33.3 \%)$ patients with grade $\mathrm{B}$, moreover, there were $11(36.7 \%)$ patients, $3(10 \%)$ patients with grades $\mathrm{C}, \mathrm{D}$, respectively. Subsequently, in non-obese group there were $14(46.7 \%)$ patients with grade A. while there were $10(33.3 \%)$ patients with grade B. on the other hand there were $4(13.3 \%)$ Patients, 2 (6.7\%) patients with grades $\mathrm{C}$ and D respectively. Interestingly, there were $15(50.0 \%)$ patients in control group with grade A reflux esophagitis. There were significant differences between the three groups $(\mathrm{p}<0.001)$ as regard as the ultrasonography findings (Table 1).

\section{Relationships With leptin, adiponectin and Interleukin-6 in obese group:}

There was significant positive correlation between BMI and leptin $(\mathrm{r}=0.512, \mathrm{p}=0.004)$, adiponectin $(\mathrm{r}=0.542, \mathrm{p}=0.002)$ and Interleukin -6 levels $(\mathrm{r}=0.442, \mathrm{p}=0.014)$. so, there was high significant positive correlation between $\mathrm{WC}$ and leptin $(r=0.406, p=0.026)$, adiponectin $(r=0.373$, $\mathrm{p}=0.042)$ and interleukin $-6(\mathrm{r}=0.696, \mathrm{p}<0.001)$. in addition, there were significant positive correlation between VAI and leptin levels $(\mathrm{r}=0.470, \quad \mathrm{p}=0.009)$, adiponectin $(\mathrm{r}=0.565$, $\mathrm{p}=0.001)$ and Interleukin $-6(\mathrm{r}=0.439, \mathrm{p}=0.015)$. Otherwise, there were significant positive correlation between US findings and leptin levels $(\mathrm{r}=0.467, \quad \mathrm{p}<0.001)$ adiponectin $(\mathrm{r}=0.443$, $\mathrm{p}=0.014)$ and Interleukin $-6(\mathrm{r}=0.395, \mathrm{p}=0.031)$.

(Table 2, and Figure .1).

Expression of Inflammatory Cytokines in Reflux Esophagitis in obese group:

There was a significant difference $(p<0.001)$ between leptin levels as regard as sex, the mean leptin levels in female was $15.60 \pm 6.24$, while the mean leptin levels in male was $6.67 \pm 2.64$. Subsequently, there were significant differences $(\mathrm{p}=0.008)$ between adiponectin levels and interleukin-6( $\mathrm{p}=0.045)$ as regard as sex. The mean adiponectin level in females was $4.07 \pm$ 1.03 while the mean level in males was $2.97 \pm$ 1.06. Also, the mean level of interleukin-6 in females was $143.33 \pm 57.28$ while the mean level in male was $104.33 \pm 43.54$ ranged from 5 to 200 .

Relationships With leptin, adiponectin, and Interleukin-6 in non-obese group:

There was no significant correlation $(p>0.05)$ between Age, BMI, WC, two hours postprandial plasma glaucous (2h-PPPG), fasting plasma glucose(FPG), aspartate transaminase (AST), alanine transaminase (ALT), high density lipoprotein (HDL), low density lipoprotein (LDL), total cholesterol; (TC), triglyceride (TG), VAI, US findings creatinine, hemoglobin $(\mathrm{Hb})$, international normalized ratio (INR) and Platelets as regarding as the levels of leptin, adiponectin and Interleukin-6. (Table 3).

\section{Expression of Inflammatory Cytokines in Reflux Esophagitis:}

The mean level of leptin in female was $11.38 \pm$ 3.4 ranged from 6 to 16 while the mean was 9.81 \pm 2.58 ranged from 2 to 7 in males. Subsequently, 
the mean level of adiponectin was $6.31 \pm 2.90$, $4.59 \pm 1.77$ in females and males, respectively. also, the mean level of interleukin-6 was 123.85 \pm 39.90 in females whilst it was $110.94 \pm 35.98$ in males. Interestingly, there was no significant difference of leptin $(\mathrm{p}=0.161)$, adiponectin $(\mathrm{p}=0.054)$ and interleukin-6 $(\mathrm{p}=0.360)$ levels as regard as the sex.

Table. 1 patient demographic characteristic

\begin{tabular}{|c|c|c|c|c|c|c|c|c|c|}
\hline & & \multirow{2}{*}{$\begin{array}{c}\text { Obese group } \\
\text { No. }=\mathbf{3 0}\end{array}$} & \multirow{2}{*}{$\begin{array}{c}\begin{array}{c}\text { Non-obese } \\
\text { group }\end{array} \\
\text { No. }=\mathbf{3 0}\end{array}$} & \multirow{2}{*}{$\begin{array}{c}\begin{array}{c}\text { Control } \\
\text { group }\end{array} \\
\text { No. }=\mathbf{3 0}\end{array}$} & \multicolumn{2}{|c|}{$\begin{array}{l}\text { One Way } \\
\text { ANOVA }\end{array}$} & \multicolumn{3}{|c|}{ Post hoc analysis } \\
\hline & & & & & $\mathbf{F} / \mathbf{X}^{2 *}$ & $\begin{array}{c}\mathrm{P}- \\
\text { value }\end{array}$ & P1 & $\mathbf{P 2}$ & $\mathbf{P 3}$ \\
\hline Age (years) & $\begin{array}{l}\text { Mean } \pm \\
\text { SD }\end{array}$ & $42.27 \pm 9.35$ & $41.77 \pm 6.58$ & $38.33 \pm 11.18$ & 1.612 & 0.205 & $\begin{array}{c}0.83 \\
4\end{array}$ & $\begin{array}{c}0.10 \\
3\end{array}$ & $\begin{array}{c}0.15 \\
4\end{array}$ \\
\hline Sex & Females & $15(50 \%)$ & $13(43.3 \%)$ & $12(40 \%)$ & $0.63^{*}$ & 0.73 & $\begin{array}{c}0.79 \\
5\end{array}$ & $\begin{array}{c}0.60 \\
3\end{array}$ & $\begin{array}{c}1.00 \\
0\end{array}$ \\
\hline $\mathrm{BMI}\left(\mathrm{kg} / \mathrm{m}^{2}\right)$ & $\begin{array}{l}\text { Mean } \pm \\
\text { SD }\end{array}$ & $30.27 \pm 2.53$ & $23.57 \pm 2.14$ & $21.03 \pm 1.59$ & $\begin{array}{c}151.46 \\
5\end{array}$ & 0.001 & $\begin{array}{c}0.00 \\
1\end{array}$ & $\begin{array}{c}0.00 \\
1\end{array}$ & $\begin{array}{c}0.00 \\
1\end{array}$ \\
\hline $\begin{array}{l}\text { waist circumference } \\
\text { (WC) }\end{array}$ & $\begin{array}{c}\text { Mean } \pm \\
\text { SD }\end{array}$ & $93.23 \pm 5.01$ & $80.53 \pm 4.02$ & $77.67 \pm 3.44$ & $\begin{array}{c}116.36 \\
6 \\
\end{array}$ & 0.001 & $\begin{array}{c}0.00 \\
1 \\
\end{array}$ & $\begin{array}{c}0.00 \\
1 \\
\end{array}$ & $\begin{array}{c}0.01 \\
0\end{array}$ \\
\hline FPG (mg/dl) & $\begin{array}{c}\text { Mean } \pm \\
\text { SD }\end{array}$ & $100.93 \pm 8.91$ & $93.40 \pm 8.24$ & $87.03 \pm 8.25$ & 20.231 & 0.001 & $\begin{array}{c}0.00 \\
1\end{array}$ & $\begin{array}{c}0.00 \\
1 \\
\end{array}$ & $\begin{array}{c}0.00 \\
5\end{array}$ \\
\hline PPG (mg/dl) & $\begin{array}{l}\text { Mean } \pm \\
\text { SD }\end{array}$ & $\begin{array}{c}147.87 \pm \\
13.88\end{array}$ & $142.97 \pm 7.64$ & $130.83 \pm 6.77$ & 23.308 & 0.001 & 0.06 & $\begin{array}{c}0.00 \\
1\end{array}$ & $\begin{array}{c}0.00 \\
1\end{array}$ \\
\hline $\mathrm{Hb}(\mathrm{g} / \mathrm{dL})$ & $\begin{array}{l}\text { Mean } \pm \\
\text { SD }\end{array}$ & $10.89 \pm 1.33$ & $11.45 \pm 1.27$ & $12.66 \pm 0.76$ & 18.573 & 0.001 & $\begin{array}{c}0.06 \\
4\end{array}$ & $\begin{array}{c}0.00 \\
1\end{array}$ & $\begin{array}{c}0.00 \\
1\end{array}$ \\
\hline INR & $\begin{array}{l}\text { Mean } \pm \\
\text { SD }\end{array}$ & $1.07 \pm 0.19$ & $1.04 \pm 0.19$ & $1.0 \pm 0.01$ & 1.595 & 0.209 & $\begin{array}{c}0.34 \\
4\end{array}$ & $\begin{array}{c}0.07 \\
8\end{array}$ & $\begin{array}{c}0.42 \\
5\end{array}$ \\
\hline Creatinine (mg/dl) & $\begin{array}{c}\text { Mean } \pm \\
\text { SD }\end{array}$ & $1.1 \pm 0.28$ & $1.05 \pm 0.16$ & $1.01 \pm 0.19$ & 1.321 & 0.272 & $\begin{array}{c}0.40 \\
2\end{array}$ & $\begin{array}{c}0.10 \\
8\end{array}$ & $\begin{array}{c}0.43 \\
6\end{array}$ \\
\hline Platelets. $\left(10^{3} / \mathrm{Cmm}\right)$ & $\begin{array}{c}\text { Mean } \pm \\
\text { SD }\end{array}$ & $\begin{array}{l}270.23 \pm \\
48.75 \\
\end{array}$ & $322 \pm 56.3$ & $250.2 \pm 45.81$ & 16.161 & 0.001 & $\begin{array}{c}0.00 \\
1\end{array}$ & $\begin{array}{c}0.12 \\
8 \\
\end{array}$ & $\begin{array}{c}0.00 \\
1\end{array}$ \\
\hline AST & $\begin{array}{c}\text { Mean } \pm \\
\text { SD }\end{array}$ & $38.27 \pm 8.59$ & $35.83 \pm 7.24$ & $20.17 \pm 3.63$ & 62.275 & 0.001 & HS & 0.17 & $\begin{array}{c}0.00 \\
1\end{array}$ \\
\hline ALT & $\begin{array}{l}\text { Mean } \pm \\
\text { SD }\end{array}$ & $53.2 \pm 13.88$ & $30.7 \pm 5.93$ & $22 \pm 3.22$ & 97.956 & 0.001 & HS & $\begin{array}{c}0.00 \\
1\end{array}$ & $\begin{array}{c}0.00 \\
1\end{array}$ \\
\hline HDL (mg/dl) & $\begin{array}{l}\text { Mean } \pm \\
\text { SD }\end{array}$ & $47.2 \pm 3.55$ & $39.07 \pm 3.69$ & $53.27 \pm 4.96$ & 89.858 & 0.001 & $\begin{array}{c}0.00 \\
1\end{array}$ & $\begin{array}{c}0.00 \\
1\end{array}$ & $\begin{array}{c}0.00 \\
1\end{array}$ \\
\hline LDL (mg/dl) & $\begin{array}{l}\text { Mean } \pm \\
\text { SD }\end{array}$ & $\begin{array}{c}139.47 \pm \\
11.49\end{array}$ & $99.19 \pm 13.56$ & $83.7 \pm 7.78$ & 200.53 & 0.001 & $\begin{array}{c}0.00 \\
1\end{array}$ & $\begin{array}{c}0.00 \\
1\end{array}$ & $\begin{array}{c}0.00 \\
1\end{array}$ \\
\hline $\mathrm{TC}(\mathrm{mg} / \mathrm{dl})$ & $\begin{array}{l}\text { Mean } \pm \\
\text { SD }\end{array}$ & $\begin{array}{c}267.47 \pm \\
24.66\end{array}$ & $223.57 \pm 30.71$ & $130.33 \pm 13.12$ & $\begin{array}{l}256.14 \\
5\end{array}$ & 0.001 & $\begin{array}{c}0.00 \\
1\end{array}$ & $\begin{array}{c}0.00 \\
1\end{array}$ & $\begin{array}{c}0.00 \\
1\end{array}$ \\
\hline $\mathrm{TG}(\mathrm{mg} / \mathrm{dl})$ & $\begin{array}{c}\text { Mean } \pm \\
\text { SD }\end{array}$ & $\begin{array}{c}217.67 \pm \\
29.93\end{array}$ & $179.90 \pm 23.18$ & $90.43 \pm 14.83$ & $\begin{array}{c}232.38 \\
1\end{array}$ & 0.001 & $\begin{array}{c}0.00 \\
1\end{array}$ & $\begin{array}{c}0.00 \\
1\end{array}$ & $\begin{array}{c}0.00 \\
1\end{array}$ \\
\hline Leptin (ng/dl) & $\begin{array}{c}\text { Mean } \pm \\
\text { SD }\end{array}$ & $11.13 \pm 1.54$ & $7.43 \pm 1.30$ & $8.7 \pm 1.13$ & 4.06 & 0.021 & $\mathrm{~S}$ & $\begin{array}{c}0.00 \\
6 \\
\end{array}$ & $\begin{array}{c}0.06 \\
9\end{array}$ \\
\hline Adiponectin (mcg/ml) & $\begin{array}{c}\text { Mean } \pm \\
\text { SD }\end{array}$ & $3.7 \pm 1.15$ & $5.33 \pm 1.44$ & $8.20 \pm 1.44$ & 24.458 & 0.001 & HS & $\begin{array}{c}0.01 \\
4 \\
\end{array}$ & $\begin{array}{c}0.00 \\
1 \\
\end{array}$ \\
\hline Interleukin (pg/ml) & $\begin{array}{c}\text { Mean } \pm \\
\text { SD }\end{array}$ & $137.50 \pm 7.07$ & $100.67 \pm 4.17$ & $74.67 \pm 4.88$ & 16.345 & 0.00 & HS & $\begin{array}{c}0.00 \\
1\end{array}$ & $\begin{array}{c}0.00 \\
1\end{array}$ \\
\hline VAI & $\begin{array}{c}\text { Mean } \pm \\
\text { SD }\end{array}$ & $5.47 \pm 1.93$ & $4.43 \pm 1.61$ & $3.10 \pm 0.88$ & 17.877 & 0.001 & HS & $\begin{array}{c}0.01 \\
1\end{array}$ & $\begin{array}{c}0.00 \\
1\end{array}$ \\
\hline Ultrasound & $\begin{array}{c}\text { Mean } \pm \\
\text { SD }\end{array}$ & $4.2 \pm 0.92$ & $3.67 \pm 1.12$ & $1.30 \pm 1.21$ & 59.928 & 0.001 & HS & $\begin{array}{c}0.06 \\
2\end{array}$ & $\begin{array}{c}0.00 \\
1\end{array}$ \\
\hline \multirow{5}{*}{$\begin{array}{c}\text { Reflux } \\
\text { Esophagitis }\end{array}$} & Negative & $0(0.0 \%)$ & $0(0.0 \%)$ & $15(50 \%)$ & 59.371 & 0.001 & HS & $\begin{array}{c}0.08 \\
3\end{array}$ & $\begin{array}{c}0.00 \\
1\end{array}$ \\
\hline & $\mathrm{A}$ & $6(20 \%)$ & $14(46.7 \%)$ & $15(50 \%)$ & & & & & \\
\hline & B & $10(33.3 \%)$ & $10(33.3 \%)$ & $0(0.0 \%)$ & & & & & \\
\hline & $\mathrm{C}$ & $11(36.7 \%)$ & $4(13.3 \%)$ & $0(0.0 \%)$ & & & & & \\
\hline & $\mathrm{D}$ & $3(10 \%)$ & $2(6.7 \%)$ & $0(0.0 \%)$ & & & & & \\
\hline
\end{tabular}

$\mathrm{BMI}=$ body mass index, $\mathrm{WC}=$ weight circumference, $\mathrm{FPG}=$ fasting plasma glaucous, $2 \mathrm{~h}-\mathrm{PPPG}=$ two hours post-prandial plasma glaucous, $\mathrm{Hb}=$ hemoglobin, $\mathrm{LDL}=$ low density lipo-protein, $\mathrm{TC}=$ total cholesterol, $\mathrm{TG}=$ triglyceride, $\mathrm{VAI}=$ visceral adiposity index, $\mathrm{INR}=$ international normalized ratio, AST= aspartate transaminase, ALT= alanine transaminase, HDL=high density lipo-protein. 
The Role of Visceral Fat, IL-6, Adiponectin and Leptin Levels on Reflux Esophagitis in Obese Patients

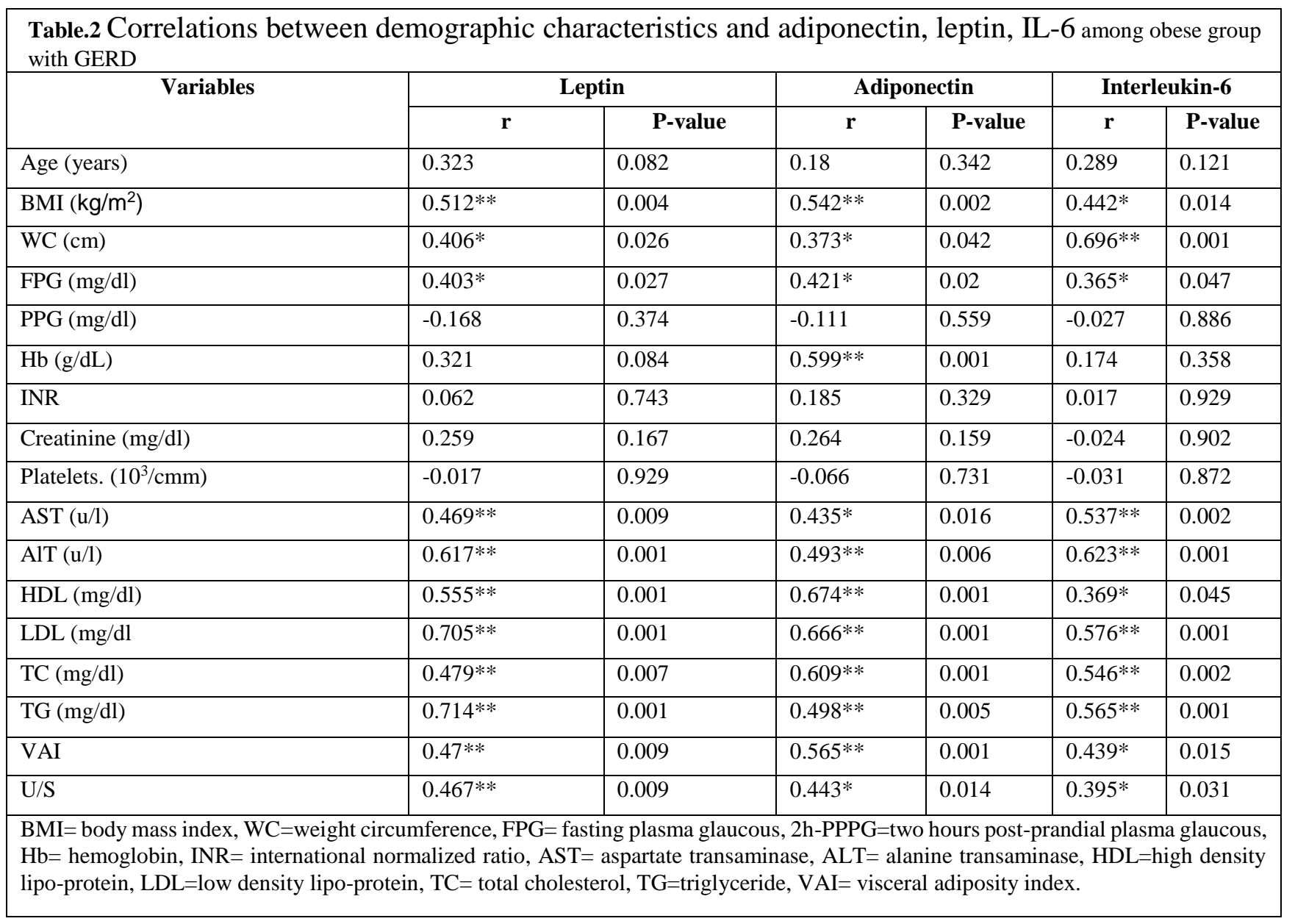

\begin{tabular}{|c|c|c|c|c|c|c|}
\hline Variables & $\mathbf{r}$ & P-value & $\mathbf{r}$ & P-value & $\mathbf{r}$ & P-value \\
\hline Age (years) & -0.037 & 0.847 & 0.197 & 0.297 & 0.279 & 0.136 \\
\hline BMI $\left(\mathrm{kg} / \mathrm{m}^{2}\right)$ & -0.042 & 0.824 & 0.058 & 0.762 & 0.146 & 0.442 \\
\hline WC $(\mathrm{cm})$ & 0.031 & 0.873 & 0.004 & 0.983 & -0.118 & 0.535 \\
\hline FPG $(\mathrm{mg} / \mathrm{dl})$ & 0.169 & 0.373 & 0.106 & 0.578 & 0.091 & 0.632 \\
\hline PPG (mg/dl) & -0.058 & 0.759 & -0.15 & 0.429 & -0.068 & 0.72 \\
\hline $\mathrm{Hb}(\mathrm{g} / \mathrm{dL})$ & 0.234 & 0.213 & 0.234 & 0.214 & 0.245 & 0.191 \\
\hline INR & 0.172 & 0.382 & -0.05 & 0.8 & -0.115 & 0.559 \\
\hline Creatinine $(\mathrm{mg} / \mathrm{dl})$ & -0.172 & 0.363 & -0.169 & 0.371 & -0.123 & 0.517 \\
\hline Platelets. $\left(10^{3} / \mathrm{cmm}\right)$ & -0.272 & 0.146 & -0.141 & 0.459 & -0.353 & 0.056 \\
\hline $\operatorname{AST}(\mathrm{u} / \mathrm{l})$ & $\begin{array}{l}-0.073 \\
\end{array}$ & 0.702 & $\begin{array}{l}-0.078 \\
\end{array}$ & 0.683 & $\begin{array}{ll}-0.132 \\
\end{array}$ & 0.486 \\
\hline $\operatorname{AlT}(\mathrm{u} / \mathrm{l})$ & $\begin{array}{l}-0.13 \\
\end{array}$ & 0.495 & 0.238 & 0.205 & 0.058 & 0.760 \\
\hline HDL $(\mathrm{mg} / \mathrm{dl})$ & -0.014 & 0.94 & 0.237 & 0.208 & 0.289 & 0.121 \\
\hline $\mathrm{LDL}(\mathrm{mg} / \mathrm{dl}$ & -0.077 & 0.701 & 0.276 & 0.164 & 0.155 & 0.441 \\
\hline $\mathrm{TC}(\mathrm{mg} / \mathrm{dl})$ & -0.053 & 0.781 & 0.324 & 0.081 & 0.167 & 0.378 \\
\hline $\mathrm{TG}(\mathrm{mg} / \mathrm{dl})$ & -0.054 & 0.776 & 0.251 & 0.18 & 0.084 & 0.661 \\
\hline VAI & 0.124 & 0.513 & 0.171 & 0.367 & 0.143 & 0.45 \\
\hline $\mathrm{U} / \mathrm{S}$ & 0.07 & 0.714 & 0.057 & 0.766 & 0.004 & 0.982 \\
\hline
\end{tabular}


1

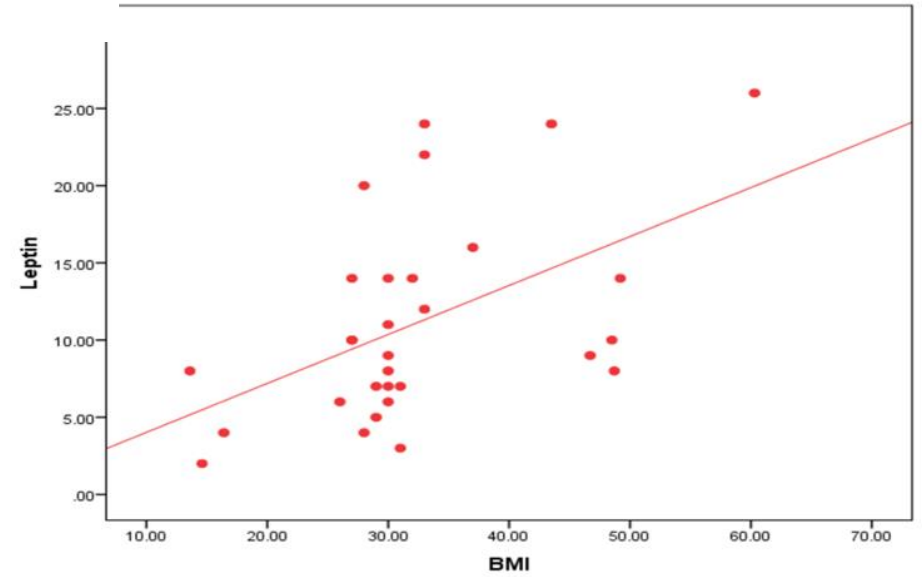

3

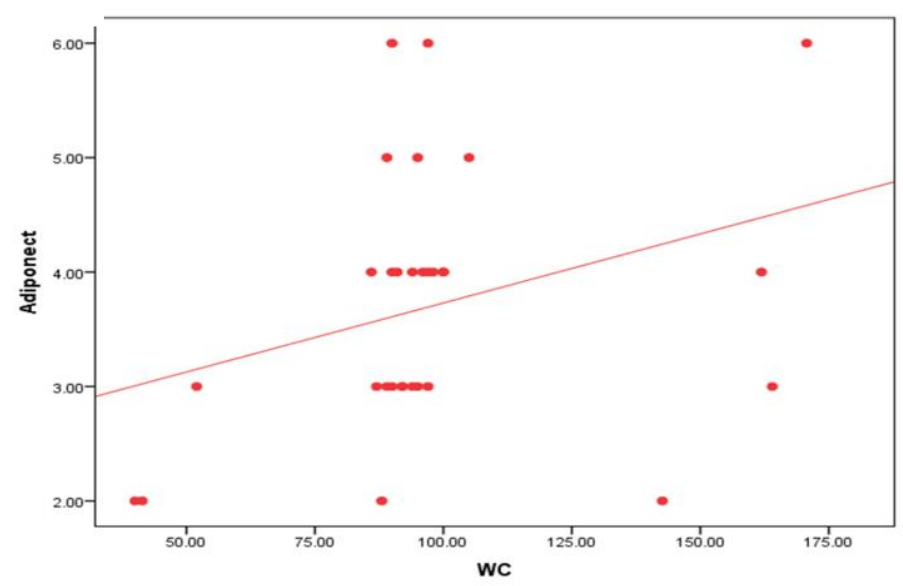

\section{Discussion}

Gastroesophageal reflux disease (GERD) includes the whole spectrum of reflux disease, from intermittent symptoms like heartburn or acid regurgitation to endoscopic reflux esophagitis and BE. It usually gives a considerable impact on the quality of the patient's life not only by the symptoms, but also by the following consultation procedures and medical cares ${ }^{(\mathbf{1 2})}$. The evidence retrieved in this study brings to light that; the mean levels of BMI, WC, FBS, PPG, creatinine, AST, ALT, LDL, TC, TG and U/S findings were elevated in obese group in comparison with non-obese and control groups. Subsequently, the mean levels of $\mathrm{Hb}$ and HDL were low in obese group in comparison with non-obese and control groups. Moreover, the levels of inflammatory cytokines showed significant differences in the three groups. As

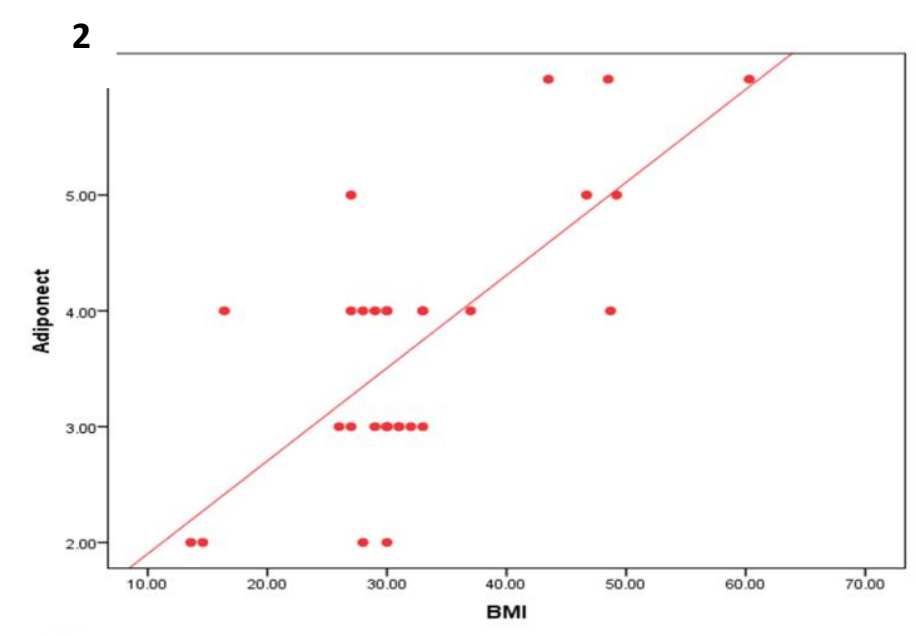

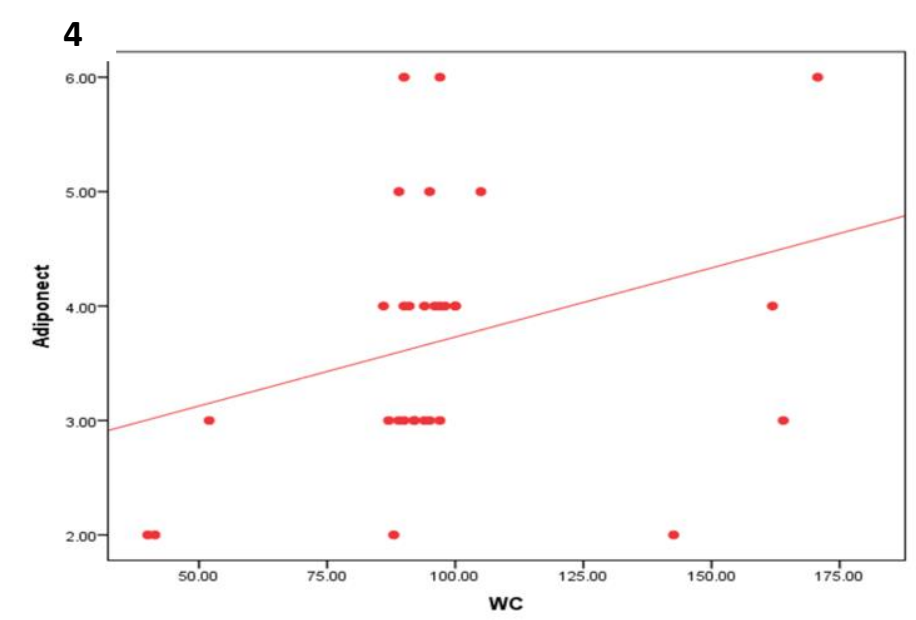

regard, the mean levels of leptin and interleukin-6 was high in obese group in comparison with other groups. Interestingly, the mean level of adiponectin was high in nonobese group in comparison with obese and control groups.

In compliance with our result, a large study including 8,571 Korean men, who underwent comprehensive screening and endoscopy, demonstrated that high BMI increased the risk of reflux esophagitis with a dose-dependent pattern. Furthermore, weight gain increased the risk of new development of reflux esophagitis $^{(\mathbf{1 2})}$. Subsequently, Abdominal visceral adiposity, rather than BMI, appears to be more closely associated with reflux esophagitis. A large cross-sectional study using 5,329 comprehensive screening 
individuals demonstrated that odds ratio $(\mathrm{OR})$ for erosive esophagitis correlated with obesity measured by BMI, waist circumference, and abdominal visceral adipose tissue volume $(\mathrm{p}<0.001 \text { for each factor })^{(\mathbf{6})}$.

Of note, the pathophysiological mechanism in obesity includes lower esophageal sphincter abnormalities, increased risk of hiatal hernia, and increased intragastric pressure. Moreover, alterations in the secretion of adiponectin and leptin from adipocytes is a proposed link between obesity and Barrett's esophagus. The data for weight reduction as a treatment for GERD is less robust, but weight reduction appears to be an association with fewer GERD symptoms. In lean person, diet-induced weight reduction correlated with improvement in reflux symptoms ${ }^{(\mathbf{1 3})}$

Wang et al. reported that the prevalence of GERD symptoms in type II DM patients in USA was approximately $41 \%{ }^{(14)}$. Subsequently, Sun et al. reported that laboratory parameters including FBG, TG, TC and LDL was high in GERD group in comparison with non-GERD group. also, HDL level was low in GERD group ${ }^{(15)}$. In 2012, Hirata et al. investigated 66 Japanese type II DM outpatients by Frequency Scale for the Symptoms of GERD (FSSG), and their results showed that the prevalence of GERD symptoms in type II DM was $23 \%{ }^{(16)}$.

In contrast with our results, Catanzaro et al. announced that Patients with NAFLD were more likely to experience GERD symptoms than controls. In the NAFLD group, we found a higher prevalence of heartburn, both heartburn and regurgitation, and belching. Subsequently, Patients with NAFLD have shown up to a four-times higher risk of developing symptoms than controls, and this association persisted after adjustment for potential confounding factors, including BMI and other components of metabolic syndrome. Even if it has been considered as a related risk factor for GERD ${ }^{(17)}$. This results may be explained by high-fat diet or excessive caloric intake, that is long-term responsible for an increase in weight and obesity, can determine frequency and severity of esophageal exposure to acid, reducing LES pressure and increasing the number of transient LES relaxations ${ }^{(\mathbf{1 8})}$.

Despite the strength obtained in our study, the case-control design involving cross-sectional assessments, and the small sample size were limited in establishing a causal relationship. Longitudinal studies should be used to clarify the causality of the association. The casecontrol study can have selection bias compared to population-based studies. To minimize the selection bias, we selected ageand sex-matched controls from the same period and the same population undergoing a health check-up. However, even if sample size increases, the effect on the main outcomes will be limited. Only patients with newly diagnosed reflux esophagitis were enrolled, reducing the potential effects of previous acid suppression treatment. The selection of persons undergoing a health check-up was not influenced by the presence of the outcome conditions, which reduces the risk of selection bias. Finally, we measured several important potential confounders and adjusted for those in our analyses.

\section{Conclusions}

Inflammatory cytokines, adipokines, and visceral fat referring abdominal obesity had an association with reflux esophagitis. so, a significant association was established between degrees of GERD and levels of leptin, adiponectin, and interleukin-6. also, to overcome the limitations of the present study, high-quality randomized control trials should be conducted to overcome the limitations of the study.

\section{References}

1.Tack J, Pandolfino JE (2018): Pathophysiology of Gastroesophageal Reflux Disease. Gastroenterology, 154(2): 277-88.

2.Nadaleto BF, Herbella FA, Patti MG(2016): Gastroesophageal reflux disease in the obese: Pathophysiology and treatment. Surgery,159(2): 475-86.

3.Gyawali CP, Roman S (2017): Classification of esophageal motor findings in gastroesophageal reflux disease. 
https://www.ncbi.nlm.nih.gov/pubmed/2854435 7

4.Gyawali CP, Fass R (2018): Management of Gastroesophageal Reflux Disease. Gastroenterology, 154(2): 302-18.

5.Bredenoord AJ, Fox M, Keller J, Pandolfino JE, Sifrim D, Tatum $\mathrm{R}$ et al.(2017): Pathophysiology of Gastroesophageal Reflux Disease. Neurogastroenterology and motility : the official journal of the European Gastrointestinal Motility Society,41(7): 1666-71.

6.Chung SJ, Kim D, Park MJ, Kim YS, Kim JS, Jung HC et al. (2008): Metabolic syndrome and visceral obesity as risk factors for reflux oesophagitis: a cross-sectional case-control study of 7078 health check-up Koreans. Gut,180(10):1275-93.

7.Kinoshita Y, Ishihara S, Ishimura N (2017): Future perspective of research and clinical practice in gastroesophageal reflux disease. The Japanese journal of gastro-enterology,114(10) :1765-73.

8.Souza RF, Bayeh L, Spechler SJ, Tambar UK, Bruick RK (2017): A new paradigm for GERD pathogenesis. Not acid injury, but cytokine-mediated inflammation driven by HIF2alpha: a potential role for targeting HIF-2alpha to prevent and treat reflux esophagitis. Current opinion in pharmacology,(37):93-9.

9.Iwakiri K, Kinoshita Y, Habu Y, Oshima T, Manabe N, Fujiwara Y et al. (2016): Evidencebased clinical practice guidelines for gastroesophageal reflux disease 2015. Journal of gastroenterology, 51(8): 751-67.

10.Hamaguchi M, Kojima T, Itoh Y, Harano Y, Fujii K, Nakajima T et al. (2007): The severity of ultrasonographic findings in nonalcoholic fatty liver disease reflects the metabolic syndrome and visceral fat accumulation. The American journal of gastroenterology,102(12): 2708.

11.Amato MC, Giordano $C$, Galia $M$, Criscimanna A, Vitabile S, Midiri M et al.
(2010) Visceral adiposity index (VAI): a reliable indicator of visceral fat function associated with cardiometabolic risk. Diabetes care, 108(18) :3467.

12.Nam S, Choi I, Nam B, Park K, Kim C (2009): Obesity and weight gain as risk factors for erosive oesophagitis in men. Alimentary pharmacology \& therapeutics,29(9):1042-52.

13.Fraser-Moodie C, Norton B, Gornall C, Magnago S, Weale A, Holmes G (1999): Weight loss has an independent beneficial effect on symptoms of gastro-oesophageal reflux in patients who are overweight. Scandinavian journal of gastroenterology,34(4): 337-40.

14.Wang X, Pitchumoni C, Chandrarana $K$, Shah N(2008): Increased prevalence of symptoms of gastroesophageal reflux diseases in type 2 diabetics with neuropathy. World journal of gastroenterology,14(5):709.

15.Sun H, Yi L, Wu P, Li Y, Luo B, Xu S (2014): Prevalence of gastroesophageal reflux disease in type II diabetes mellitus. Gastroenterology research and practice, 67(9): 1369-41.

16.Hirata A, Kishida K, Nakatsuji H, Inoue K, Hiuge-Shimizu A, Funahashi T et al. (2012): High prevalence of gastroesophageal reflux symptoms in type 2 diabetics with hypoadiponectinemia and metabolic syndrome. Nutrition \& metabolism,9(1): 4.

17.Catanzaro R, Calabrese F, Occhipinti S, Anzalone MG, Italia A, Milazzo $M$ et al. (2014): Nonalcoholic fatty liver disease increases risk for gastroesophageal reflux symptoms. Digestive diseases and sciences,59(8): 1939-45.

18.Hajar N, Castell DO, Ghomrawi H, Rackett R, Hila A (2012): Impedance $\mathrm{pH}$ confirms the relationship between GERD and BMI. Digestive diseases and sciences,57(7): 1875-9. 